\title{
ACCESSION TO THE EUROPEAN UNION: IMPACT OF LEGISLATION CHANGE ON PERFORMANCE OF LITHUANIAN COMPANIES
}

\author{
Irina Travkina ${ }^{1}$, Gitana Dudzevičiūtè $\dot{e}^{2}$ Liuda Maciukevičienè ${ }^{3}$ \\ 1,2Vilnius Gediminas Technical University, Sauletekio al. 11, LT-10223 Vilnius, Lietuva \\ ${ }^{3}$ Vilnius College of Law and Economics, Laisves pr. 58, LT-05120 Vilnius, Lithuania \\ E-mails: ${ }^{1}$ Irina.Travkina@vv.vgtu.lt; ${ }^{2}$ Gitana.Dudzeviciute@vv.vgtu.lt, ${ }^{3}$ liuda.maciukeviciene@post.vtvk.lt
}

Received 10 September 2008; accepted 15 February 2009

\begin{abstract}
The paper focuses on implications of the EU accession for competitiveness of New Member States, and specifically, Lithuania. Basing on a case study analysis of internationally trading Lithuanian company, effects on its performance, caused by European trade regulation, are being revealed. Authors raise a question whether the EU accession facilitated international trade for newcomers, and if not, what reasons conditioned unfavourable effects. Subjective and objective factors impacting business activity in the after-transition years are being considered.
\end{abstract}

Keywords: international trade, Lithuania's accession to the EU, competitiveness, banana trade case.

\section{PRISIJUNGIMAS PRIE EUROPOS SĄJUNGOS: JURIDINIŲ NUOSTATŲ ITTAKA LIETUVOS İMONIŲ VEIKLAI}

\author{
Irina Travkina ${ }^{1}$, Gitana Dudzevičiūtè ${ }^{2}$, Liuda Maciukevičiené ${ }^{3}$ \\ 1,2Vilniaus Gedimino technikos universitetas, Sauletekio al. 11, LT-10223 Vilnius, Lietuva \\ ${ }^{3}$ Vilniaus teises ir verslo kolegija, Laisves pr. 58, LT-05120 Vilnius, Lietuva \\ El.paštas: ${ }^{1}$ Irina.Travkina@vv.vgtu.lt; ${ }^{2}$ Gitana.Dudzeviciute@vv.vgtu.lt; ${ }^{3}$ liuda.maciukeviciene@post.vtvk.lt
}

Iteikta 2008-09-10; priimta 2009-02-15

Santrauka. Nagrinejjama naujųjų Europos Sąjungos narių, ir ypač Lietuvos, įmonių konkurencingumo pokyčiai, nulemti pakitusių ùkinès veiklos teisinio reguliavimo normų. Remiantis tarptautine prekyba užsiimančios įmonès veiklos pavyzdžiu siekiama atskleisti, kiek pakitusios juridinès veiklos sąlygos lemia veiklos rezultatus. Autoriai kelia klausimą - ar prisijungimas prie Europos Sąjungos palengvino tarptautinę prekybą, ir jei ne, tai kokios priežastys lėmè nepageidaujamus rezultatus. Aptariami subjektyvūs ir objektyvūs veiksniai, veikiantys Lietuvos įmones ịstojus ị ES.

Reikšminiai žodžiai: tarptautinė prekyba, Lietuvos įstojimas ị ES, konkurencingumas, prekyba bananais. 


\section{Introduction}

Almost unanimous agreement exits that globalization processes considerably affect international business environment. The liberalization of markets and reduced or modified trading barriers, as it is believed, open new business opportunities. In some cases, alas, globalization brings new unexpected challenges. One of the greatest challenges is the growing competition, or changing conditions, which expose trading companies to new restrictions of both economic and political character. Under globalization the response to this challenge depends on the qualities of the organization (Čiburiene 2006), on competing products cost level and structure (Tvaronavičienè et al. 2008a, b) and on specifics of economic activity (Tvaronavičienè, Travkina 2006).

Generally, country's ability to occupy a global market share depends on its competitiveness. There are a lot of criteria elaborated for country's competitiveness measuring. For example, World Competitiveness Yearbook (2008) uses 331 criteria such as: economic performance, government efficiency, business efficiency, infrastructure, etc. It is notable that those criteria are intertwined and, finally, affect countries' economic growth and sustainable development (Grybaité, Tvaronavičienè 2008).

In this paper we concentrate on the external factors that affect Lithuanian companies' economic performance with a special focus on the degree of redirection of international trade caused by changing legal conditions. It is being aimed to scrutinize change of international trade conditions as Lithuania globalizes, and to reveal some unexpected implications for its competitiveness. The article is structured as follows: at first we overview transformation of foreign trade legal conditions after Lithuania has regained independence, including changes in trade policy after the EU accession. Analysis of a particular case study let us disclose controversial impact of adoption of new regulation on Lithuania's ability to compete in international markets.

\section{Foreign trade reforms in Lithuania}

Lithuania became an independent state in 1990, what has led to radical political, economic and social changes. Changes in foreign trade were partially conditioned by change of economic policy and new agreements. Specifically, foreign trade was liberalized due to a number of unilateral decisions and treaties, which created the current Lithuanian foreign trade regime and trade policy-making structure. A bilateral and regional free trade agreement, particularly with the EU and the two other Baltic countries, was another important factor in the development of Lithuania's foreign trade policy. WTO commitments have already carried out a positive role in removing trade barriers and measures that discriminate foreign products and services.
The main areas, which still needed further liberalizing by elimination of both tariff and non-tariff barriers restricting trade and access to the market, were agriculture and infrastructure (Bagdanavičius 1999).

From 1st of May 2004 Lithuania applies European Union's contractual relations with third countries and international organizations. Thus, the foreign trade policy making is delegated to the Council and the European Commission as Republic of Lithuania joined the European Union's common trade policy area.

Enlargement of the European Union has opened additional opportunities for business in Lithuania as it joined the common market, with more than 450 million consumers. For the new EU Member State it is important to cope with increased competition, and, on the other hand, to penetrate larger markets in order to increase its own economic growth.

Lithuanian-made products now obtain the EU origin and, respectively, other countries apply corresponding customs tariffs. In Lithuania free trade (preferential) agreements with Macedonia, Algeria, Egypt, Israel, Lebanon, Morocco, Palestine, Syria, Tunisia, Jordan, South Africa, Mexico, Chile, and ACP (Africa-Caribbean-Pacific Ocean) countries are valid.

The European Union imposes quantitative restrictions on many categories of textile and clothing imports from third countries. For import licenses for these goods, Lithuanian enterprises must apply to the Ministry of Economy of Lithuania. For World Trade Organization member countries, these restrictions will be valid until 1 January 2005, the other Member restrictions will remain for a longer period, as provided for in the European Union and the countries with corresponding treaties. Special provisions for China's market protection remain until the year 2009.

The European Union restricts steel imports from Kazakhstan, Russia and Ukraine. Import licenses are being issued by Ministry of Economy of Lithuania.

Since 1 January 2005, the European Union had also imposed quantitative restrictions on the ceramics, dishes, and cutlery and footwear imports from China. Licenses for import from China have to be taken from Ministry of Economy of Lithuania.

Since the beginning of the EU membership in the European Commission's communication on the autonomous tariff suspensions and quotas, Lithuania has had the possibility to apply to the European Commission for suspension of customs duties and granted quotas. The main goal is to help European companies to bring in raw materials, semi-manufactured products or components in excess of planned quantities. In order to facilitate the European Union exporter's access to other markets, the European 
Commission gathers information about the various trade restrictions on European Union origin goods, analyses their import procedures and announces data in the special database.

Lithuania, like any of the EU countries, applies relatively low conventional duties, despite suffering itself from certain free trade distortions, especially in the area of trade with the EU in "sensitive" agricultural products and textile goods. Lithuania's accession to the EU impacts trade with Russia which remains an important source of imports. Introduction of a free trade with Russia, instead, would significantly enhance Lithuanian competitiveness.

\section{Lithuanian foreign trade development in the period of 1990-2009}

Analysis of Lithuanian foreign trade development according to the above-mentioned reforms and statistical data is made in three stages:

- the first period after the Declaration of Independence (1990-1997);

- the second period during and after the crisis in Russia and other CIS countries (1998-2003);

- the third period after the EU accession (the year 2004).

The first period was characterized by dominant trade relationships with the two most important Lithuania's foreign trade partners of the integrated economic systems: the East, represented mainly by states of the Commonwealth of Independent States (CIS), and the West, represented by the European Union. Lithuanian trade with the European Free Trade Association (EFTA), the Central European Free Trade Association (CELP) countries changed gradually as treaties were signed, shares of the United States and Japan changed respectively as international relationships were shifting towards European countries.

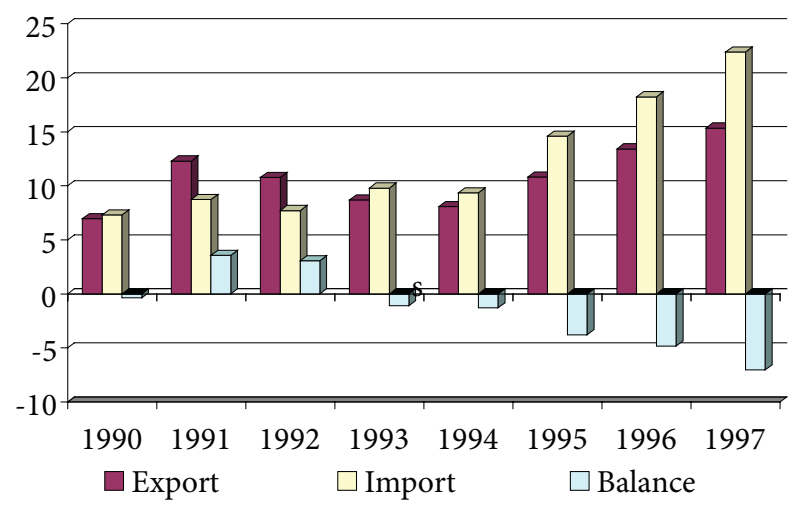

Source: Department of Statistics to the Government of the Republic of Lithuania (Statistics Lithuania)

Fig. 1. Lithuania’s foreign trade in 1990-1997 (billion LTL)
Despite trade volumes were increasing during the entire considered time span, including all three conditionally distinguished periods, trade balance was negative. As it can be observed in Fig. 1, only the years 1991-1992 yielded the positive trade balance. Alas, it was partly conditioned by the fast rise in the price level in Lithuania, and respectively by more expensive export. It was favourable for Lithuania that the major foreign partners, CIS countries, continued to import goods. Since the end of 1992 the liberalization of prices in CIS countries started, what led to the increase in imported energy resources prices. Although in the period of 1993-1997 trade volumes continued to grow, the resulting balance appeared to be negative again. In the year 1997 it amounted to 7.136 billion Lt.

The bigger part of trade deficit accounted for complications related to difficulties with crude oil imports, which was further being refined in Lithuanian 'Mažeikių nafta.' A significant portion of exports, actually, accounted for re-exports. For example, in the year $199732 \%$ of imported agricultural and food products have been transferred to another country. Not all international movement of goods is being reflected by official statistics, because of smuggling. Anyway, despite some inaccuracies, general trends of international trade are sufficiently clear.

The foreign trade balance during the second distinguished period, i.e. in the years 1998-2003, was negative as well. This time the main factor impacting on international trade was severe crisis in Russia and other CIS countries (Fig. 2).

In the year 2001 export increased significantly. It is worth to note that records of enhanced import appeared mainly because of the increase in fuel re-exports. Fluctuations in imports of crude oil and export of refined products are determined by volumes of Russian oil supply and respective usage of Mažeikių Nafta's productive capacities (Tvaronavičiene et al. 2008c). At the very end of 2001 growth rates of export diminished, despite the fact that CIS market

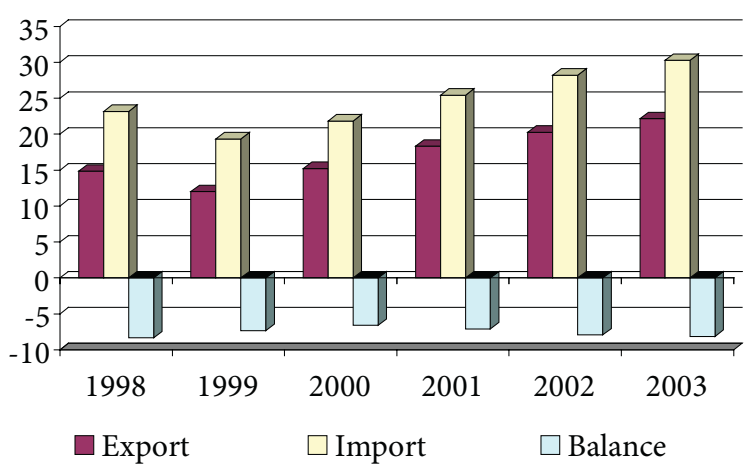

Source: Department of Statistics to the Government of the Republic of Lithuania (Statistics Lithuania)

Fig. 2. Lithuania's foreign trade in 1998-2003 (billion LTL) 
was already recovering after crisis. Lithuania gradually redirected its exports from West to East.

Later, in the year 2003, the pace of foreign trade slowed down even more considerably: the increase of the volume of imported goods was only $6.0 \%$, while the volume of exported goods increased by $9.1 \%$. The main feature of that year was that exports grew faster than imports, similarly like in the period of 2000-2001, and unlike in the year 2002. The growth of export would have been even more impressive, if not the overhaul of Mažeikių Nafta.

At the beginning of the third period (in 2004) a number of factors retarded Lithuania's export prospects. First, Mažeikių Nafta, managed by the Russian oil giant Yukos, has been in operational paralysis and there was a threat of the uncertainty in the oil supply continuity. Yukos declared concern about possible oil supply disruptions, and, in such case, it would be very difficult to maintain the flow of crude oil completely unchanged and stable. It threatened part of exports related to performance of Mažeikių Nafta (recall that export of mineral products comprise about a fifth of the total export value of Lithuania).

Second, the factor retarding successful export was conditioned by political issues: Russian officials restricted reciprocally imports from the European Union countries (including Lithuania's agricultural products). As a result of Russian new legislation adoption, right after the EU accession, the export of animal products to Russia has been completely halted. Slovenia, Malta and Cyprus stated that they had no opportunities to export agricultural products to Russia. Meanwhile, seven new EU members started successful negotiations, after which parties came to an agreement and exports of agricultural products to Russia were renewed.

In 2004 the new European Union members experienced threat of hardly predictable aspect of the EU accession side effects (example was provided above). Uncertainty regarding the future of the Baltic countries has led to roller coaster of imports during that year: until the EU accession, i.e, in March-April 2004 unexpectedly the increase in imports was recorded, which in May already changed to a downturn. Temporarily incompatible foreign trade reflection rules of methodological character could have impacted statistical May imports to Lithuania. During that month Latvia and Estonia experienced food, mineral products, metals imports decline. Fluctuations were conditioned not only by irrational inflation expectations leading to consumer goods stocks bubble. External factors, such as the global metals prices tumble, impacted the situation as well. Lithuania had an import surge "before entering the EU ", which was the highest among the Baltic countries.

During the third period imports developed more vigorously if to compare to exports. Consequent negative trade balance was quite high (Fig. 3).

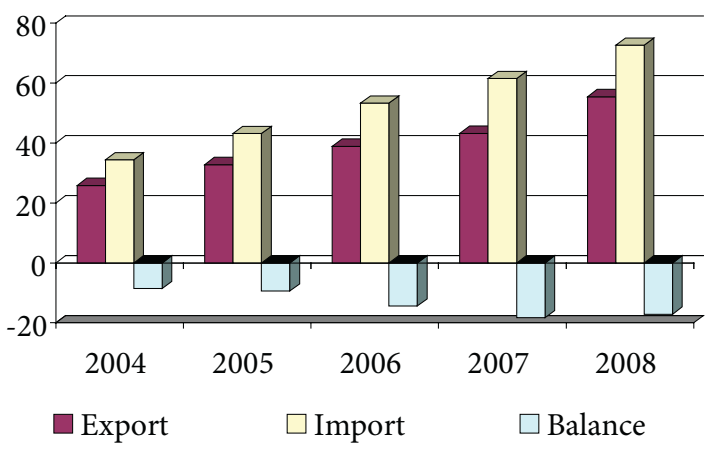

Resource: Department of Statistics to the Government of the Republic of Lithuania (Statistics Lithuania)

Fig. 3. Lithuania's foreign trade in 2004-2008 (billion LTL)

In 2008, the largest export product groups in Lithuania were mineral products ( 25 percent of total export), machinery and mechanical and electrical equipment (11 percent) and chemical products (10 percent). The largest import product groups were mineral products (30 percent of total import), machinery and mechanical and electrical equipment (14 percent), vehicles and auxiliary transport equipment (10 percent).

In 2008, Russia was the major export partner of Lithuania (16 percent of total export). Other equally significant export partners of Lithuania with strongly rising export volumes were Latvia (12 percent) and Germany (7 percent). Three major import partners of Lithuania were Russia (30 percent of total import), Germany (12 percent) and Poland (10 percent).

\section{Food products and beverages}

Exports of food products and beverages were very dynamic for the fifth consecutive years (from 2003 to 2008). The growth of exports of foods slowed down slightly only at the end of 2008, but remained strong.

For the first time food products represented the largest share of Lithuanian total exports (in $2008-16$ percent of total export, in 2003 - 12 percent, in 1998 - 14 percent)). This product group also had a heavy relative weight in the exports, as in Latvia, Estonia, Poland and Denmark.

It was expected that the domestic demand for food products and beverages may shrink next year and the situation in the neighbouring regions is less than encouraging. Authors consider, that the prospect of the food products and beverages section in the short run has become worse, but in the longrun it is constantly increasing worldwide since increasing food consumption (Fig. 4).

It should be noted that the Russian market has become a very important market for the food industry because it absorbs about a third of exported foodstuffs. This situation is similar to the period of 1997-1998, i.e. to the end of the first stage of Lithuanian foreign trade development (Fig. 5). 


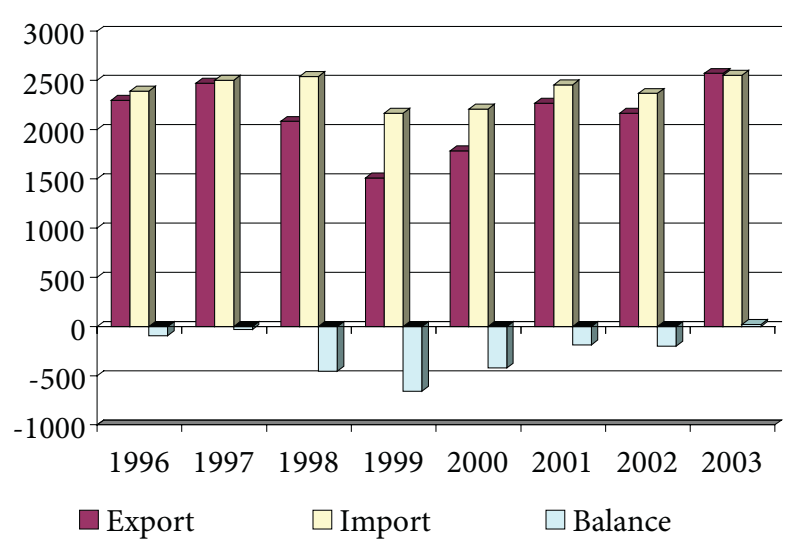

Source: Department of Statistics to the Government of the Republic of Lithuania (Statistics Lithuania)

Fig. 4. Lithuania's foreign trade in food products and beverages section (in 1996-2003, billion LTL)

\section{A case study: impact of the EU accession on Lithuanian banana's importers}

Banana is a very important fruit. According to quantities consumed it follows rice, wheat and corn. Bananas are grown in 130 countries worldwide, mostly in the third countries. India leads in banana production, but major part of Indian bananas are consumed domestically. Six main banana exporting countries in 2005, just after Lithuania's accession to the EU, shared the export market as shown in Fig. 6.

Almost three-quarters of world banana exports are generated in four countries: Ecuador, Philippines, Costa Rica and Colombia. According to the Food and Agriculture Organization of the United Nations, Ecuador alone exports more than one-third of international banana exports (Fig. 6). In 2005 a record number of 15 Atlantic hurricanes caused significant damage to Central American banana plantations. Countries like Ecuador were not exposed to hurricanes in 2005, and therefore benefited from supplying bananas at comparatively high prices (Workman 2006).

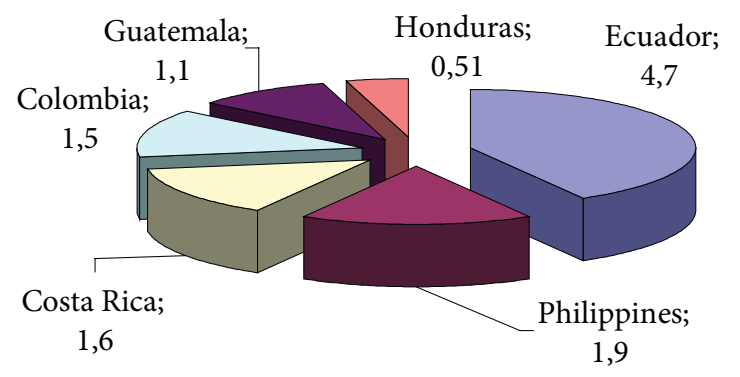

Source: Food and Agriculture Organization of the United Nations (2006)

Fig. 6. Six main banana exporting countries, 2005 (million metric tonnes)

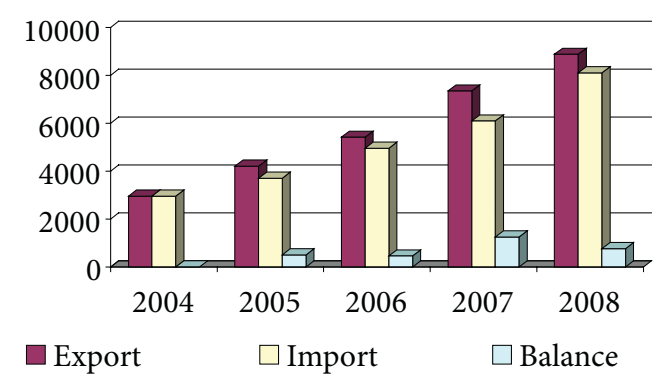

Source: Department of Statistics to the Government of the Republic of Lithuania (Statistics Lithuania)

Fig. 5. Lithuania's foreign trade in food products and beverages section (in 2004-2008, billion LTL)

In 2005 the dominant banana importers were 23 European countries (29.2\%), U.S. (27.5\%), Japan (8.2\%), Russia (7.9\%) and Canada (3.5\%) (www.fao.org).

The EU adopted a new banana import regime of gradually, through a two-step process, nearing towards a tariff-only system that came into force on 1 January 2006. Bananas continued to be imported into the EU under a tariff-rate quota system during the transitional period of 2001-2005. According to Institut National de la Recherche Agronomique, France (Guyomard, Mouel 2002), banana trade case reveals restructuring of the EU imports from non-preferred to preferred suppliers.

Transformation of trade conditions in detail is presented in Fig. 7.

NewEU members, including Lithuania, were exposed to changing banana trade conditions. In May 2004 Lithuania automatically adopted European banana trade system customized to old EU members' (so-called "traditional" importers) interests.

The traditional importers in Lithuania and other 9 countries which entered the EU appeared to be „non-traditional" for the EU market right after accession. Import regulation in the enlarged EU was being implemented by introducing a licensing system. In this context $17 \%$ of banana imports is being licensed to companies, which have not historically (looking from the EU point of view) imported bananas, while $83 \%$ of the share is attributed to "traditional" European importers (Grybè 2009).

More specifically, to traditional banana importers economic agents have been established in the EU and had purchased a minimum quantity of bananas (250 tons) originating in third countries (Guyomard, Mouel 2002). Such distinction between the so-called "traditional" and "nontraditional" importers meant that all banana importing companies originated in 10 new EU members fell under "non-traditional" importer category with all consequent implications, i.e. being attributed to non-traditional importers meant that companies from 10 new Member States may 


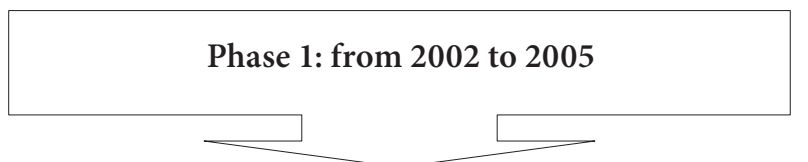

A. B, C tariff-rate quotas:

The bound Quota - A (2.2 m)

The autonomous Quota - B (0.45 mill tons net weight)

The additional Quota- C (0.75 mill tons net weight)

\section{DIFFERENCES:}

Tariff for the Quotas A/B: 75 Euros per ton for non-ACP (African, Caribbean and Pacific Group of States) countries and 0 for ACP countries

\section{SIMILARITIES:}

Tariff for Quotas A/B/C: 680 Euros per ton for nonACP countries and 380 Euros per ton for ACP countries (tariff preference of 300 Euros per ton for ACP countries)

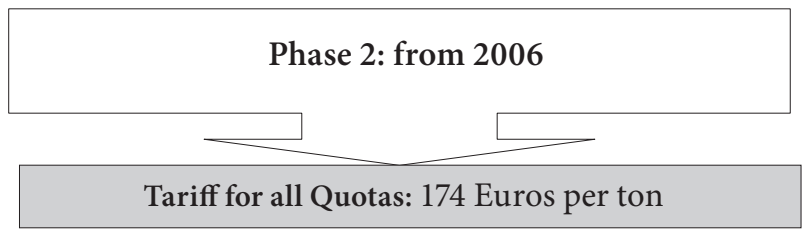

Source: WTO (2002)

Fig. 7. Transformation of banana trade conditions in the EU in 2002-2006

claim $17 \%$ of total licensed banana import volumes.

Such market regulation appeared to be discriminatory taking into account that the EU enlarged by 74.1 million people (to 3823 million, what comprised about $20 \%$ of population increase). $17 \%$ of licensed import volumes were distributed between 25 Member States but not between 10 newcomers, which, in turn, were automatically rejected of "traditional" importers status, and, respectively, licenses.
"Over the quota" tariffs for imported bananas were 900\% higher if to compare with licensed tariffs: 680 Euros against 25 Euros per ton. De jure in the enlarged EU all 25 Member States operated in equal conditions, while de facto, EU15 countries had obvious advantage in terms of exploiting "traditional" importer status and meanwhile having possibility to claim licenses attributed to quoted "non-traditional" importers as well.

Consequently, Lithuanian banana importers neither met requirements set for traditional importers, nor received quotas and respective trade licenses as non-traditional importers. Hence, during European transition from quota-tariff to tariff system Lithuanian banana importers found themselves in a discriminating position as did not receive licensed quotas with lower tariffs. Lithuanian banana importers became not competitive as "over the quota" fruit was heavily taxed.

To generalize, European Commission's Regulation No. 896/2001 in terms of banana regimehas extracted Lithuanian banana importers from the competition in the EU25 market during after-accession period. Bureaucratically, tariff-only regime seems to be a positive tool of trade lowering barriers, but, actually, process of implementation can lead to opposite consequences (Grybè 2009).

Entering the EU during transitional period for banana trade regime meant putting Lithuania into uncompetitive position, even though edible fruits and nuts comprise a small part of its imports and exports (Table 1).

The tariff-only banana trade now is liberal enough, and, it seems that any business company can engage in international trade. In reality the competition is harsh as companies which have already occupied a significant global market share can enjoy economies of scale, which is unachievable for new entries.

Fig. 8 reflects composition and volumes' fluctuations of the main importing company - Litbana. Banana import dropped significantly, according to the 2005 record. Comparative increase in volumes in 2006 is partly caused by the rising internal consumption. Another import recovery impacting factor is political. In the year 2005 Russian Federation prohibited import of fruits and vegetables from

Table 1. Edible fruits and nuts in total Lithuanian Imports and Exports, mill Lt and \%, respectively

\begin{tabular}{|c|c|c|c|c|c|}
\hline Edible fruits and nuts & 2004 & 2005 & 2006 & 2007 & 2008 \\
\hline Imports & 309.9 & 377.1 & 660.1 & 344.5 & 1218.0 \\
\hline Exports & 93.5 & 154.7 & 477.0 & 741.1 & 964.6 \\
\hline Balance & $(216.4)$ & $(222.4)$ & $(183.1)$ & 396.6 & $(253.4)$ \\
\hline$\%$ of Total Import & 0.9 & 0.9 & 1.2 & 1.4 & 1.7 \\
\hline$\%$ of Total Export & 0.4 & 0.5 & 1.3 & 1.7 & 1.7 \\
\hline
\end{tabular}

Resource: Department of Statistics to the Government of the Republic of Lithuania (Statistics Lithuania) 
Poland, which switched fruit routes. Actually, the same Polish production was channeled through Lithuania, what is vividly reflected in Fig. 9 and Table 2 (in the year 2006 Russia reappears as important export destination). Fig. 9 illustrates the process of export redirection towards the EU market. That clear tendency undoubtedly was conditioned by the EU accession.

\section{Conclusions}

Membership in WTO and the EU had a great impact on foreign trade processes in Lithuania. However, competitiveness of some Lithuanian companies was subjected to regulation change caused by globalization.

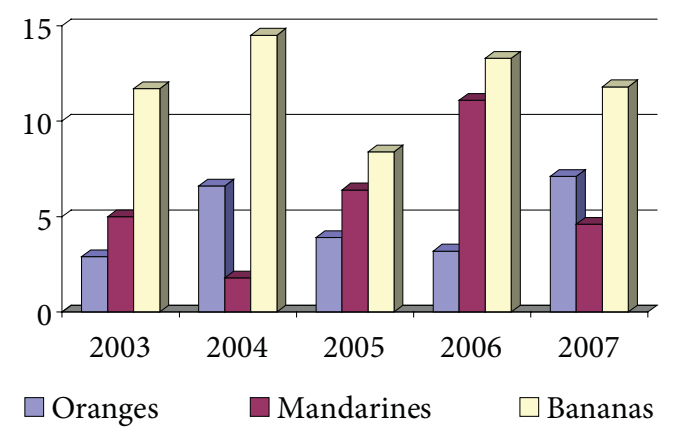

Fig. 8. Litbana's imports by main commodities, million tons

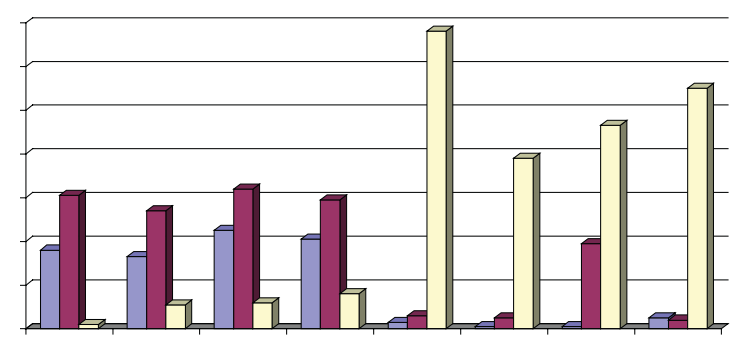

Fig. 9. Litbana UAB exports of green bananas, million tons
Presented case study verifies that free trade principle does not automatically guarantee equal conditions for competition between old and new companies, originated in New Member States. Legislation change in both the EU and third countries affected performance of Lithuanian companies. Despite changing trade directions, generally, implications of the EU accession for exports were reflected in substantial export shift towards the European market.

\section{References}

Bagdanavičius, J. 1999. Tarptautinès prekybos politikos pokyčiai, Lietuvos ūkis 11/12: 41-43.

Čiburienè, J.; Bernatonyte, D.; Simanavičienè, Ž.; Trapenskas, V. 2006. Education as factor to achieve productivity growth: Lithuanian case, in The Next Decade Challenges for Business: International Scientific Conference. February 2-3, Riga, Latvia Proceedings. Riga: RISEBA, 236-244. ISBN 9984-705-20-X,

Department of Statistics to the Government of the Republic of Lithuania. Available from Internet: <http://www.stat. gov.lt>.

Food and Agriculture Organization of the United Nations. 2006. Available from Internet: <http://www.fao.org/>.

Grybaitè, V.; Tvaronavičiene, M. 2008. Estimation of sustainable development: germination at institutional level, Journal of Business Economics and Management 9(4): 327-335.

Grybe, N. 2009. Analysis of chants in trade between Lithuania and non-European countries after EU accession: baigiamasis magistro darbas. Vilniaus Gedimino technikos universitetas.

Guyomard, H.; Mouel, C. L. 2002. The New Banana Import Regime in the European Union: A Quantitative Assessment. Institut National de la Recherche Agronomique, France. Available from Internet: <http://w3.rennes.inra.fr/economie/pdf/WP02-04.pdf $>$.

The IMD World Competitiveness Yearbook (WCY). 2008. IMD International. Available from Internet: < http://www.imd. ch/research/publications/wcy/index.cfm $>$.

Tvaronavičienė, M.; Grybaite, V.; Korsakienè, R. 2008a. Foreign capital destinations: Baltic States versus India, Journal of Business Economics and Management 9(3): 227-235.

Tvaronavičienė, M.; Grybaite, V.; Tvaronavičius, V. 2008b. Economic and other development aspects of Baltic countries: estimation issues, in $5^{\text {th }}$ International Scientific Conference: Business and Management' 2008. Selected papers. Vilnius, Lithuania May 16-17, 107-115. ISBN 978-9955-311-9.

Table 2. Litbana UAB exports of green bananas, million tons

\begin{tabular}{lcccccccc}
\hline & 2000 & 2001 & 2002 & 2003 & 2004 & 2005 & 2006 & 2007 \\
\hline Belarus & 3.637 .710 & 3.313 .775 & 4.472 .397 & 4.078 .977 & 290.491 & 100.649 & 138.259 & 459.765 \\
\hline Russia & 6.071 .618 & 5.360 .519 & 6.406 .407 & 5.943 .653 & 583.408 & 510.366 & 3.854 .870 & 382.716 \\
\hline ES/Lithuania & 249.565 & 1.072 .104 & 1.208 .756 & 1.631 .591 & 13.640 .473 & 7.815 .055 & 9.297 .513 & 10.990 .485 \\
\hline
\end{tabular}


Tvaronavičienė, M.; Kalašinskaitè, K.; Peleckis, K. 2008c. Lietuvos ūkio strateginès įmonès „Mažeikių nafta“ privatizavimo atvejis, Verslas: teorija ir praktika [Business: Theory and Practice] 9(2): 97-105.

Tvaronavičienè, M.; Travkina, I. 2006. Naujų Europos Sąjungos narių telekomų plètros tendencijos globalizacijos kontekste, Verslas: teorija ir praktika [Business: Theory and Practice] 7(2): 108-114.
Workman, D. 2006. Top Ten Banana Countries: India Produces Most Bananas but Ecuador is King of Banana Exports. Available from Internet: < http://internationaltrade.suite101. com/article.cfm/top_ten_banana_countries $>$.

WTO: WT/DS27/58, 2 July 2001, Commission Regulation (EC) 896/2001 of 7 May 2001, Council Regulation (EC) 2587/2001 of 19 December 2001; Commission Regulation (EC) 349/2002 of 25 February 2002.

Irina TRAVKINA. PhD student of Vilnius Gediminas Technical Univesity, Enterprise Economics and Management Department. Research interests: competitiveness, international trade.

Gitana DUDZEVIČIŪTĖ. Dr, Associate Professor of Vilnius Gediminas Technical Univesity, Enterprise Economics and Management Department. Research interests: financial markets, economic growth.

Liuda MACIUKEVIČIENĖ. Master of Economics, Head of Department at Vilnius College of Law and Economics. Research interests: international economics. 